\title{
Determination of anionic profiling of improvised explosive devices from different types of low explosive material
}

\author{
Mohamad Afiq Mohamed Huri ${ }^{1 *}$, Umi Kalthom Ahmad ${ }^{1}$, Mustafa Omar $^{2}$ \\ ${ }^{1}$ Department of Chemistry, Faculty of Science, UTM, 81310 UTM Johor Bahru, Johor, Malaysia, \\ ${ }^{2}$ Institut Penyelidikan Sains \& Teknologi Pertahanan (STRIDE), 48100 Batu Arang, Selangor. \\ *Corresponding Author: afiqhuri91@gmail.com (Mohamad Afiq Mohamed Huri)
}

\section{Article history :}

Received 10 March 2014

Revised 21 April 2014

Accepted 19 June 2014

Available online 5 July 2014

\section{GRAPHICAL ABSTRACT}

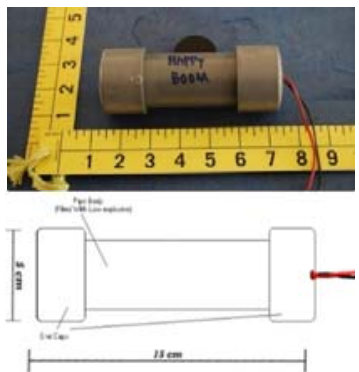

\section{ABSTRACT}

Improvised explosive devices or also known as homemade explosive devices are frequently abused for public terrorism. This types of explosive devices are well fabricated and made in improvised manner by incorporating military or commercially sourced explosive. It is often used for terrorism as the material of the devices are readily available at low cost and can be obtain legally without any suspicion from the sellers. Chemical composition of explosives holds a lot of useful information in establishing a link between a perpetrator and a bombing case. Analysis of post-blast explosive and pre-blast explosive is equally important since the chemical reaction during explosion will change the product of the composition. Different types of explosive material are also expected to give different composition profiling. In this study, four types of pyrotechnics explosives packed in pipe bombs were utilized via sampling exercise. Cotton swabbing technique was employed as method extraction as it is easy to perform, rapid, less solvent use and lab time are reduced.The determination of anionic inorganic constituents of improvised explosives were performed using ion chromatography. Post blast residues were analyzed to compare the changes of inorganic ions to its origin from pre blast samples. Inorganic ions were separated using Metrosep A SUPP 5 column and an eluent consisting of $1.0 \mathrm{mmol} / \mathrm{L}$ of $\mathrm{NaHCO}_{3}$ with $3.2 \mathrm{mmol} / \mathrm{L} \mathrm{Na}_{2} \mathrm{CO}_{3}$. Anions of interest including $\mathrm{NO}_{2}{ }^{-}, \mathrm{NO}_{3}{ }^{2-}, \mathrm{PO}_{4}{ }^{2-}, \mathrm{SO}_{4}{ }^{2-}, \mathrm{SCN}^{-}$, and $\mathrm{ClO}_{4}{ }^{-}$have been successfully separated within 60 minutes. Types and amount of anion detected are different from different materials of explosive devices.

Keywords: low explosive, ion chromatography, home-made explosive devices

(C) 2014 Penerbit UTM Press. All rights reserved http://dx.doi.org/10.11113/mjfas.v10n3.268

\section{INTRODUCTION}

In recent years, improvised explosives have been used by terrorists to increase the damage of explosion. Increasing cases involving homemade explosives in international and local media have raised the awareness of law enforcers and forensic researchers to study explosives components in depth [1].

The Altantuya murder on October 2006 by using C4 explosive has attracted international attention as the cases involved high profile people from Mongolian [2]. In The Bali bombing on 12 October 2012, two bombs exploded almost simultaneously in a night on tourist island, Kuta, has killed 203 people and injured more than 350 people [3]. In a rally on 9 January 2012, two out of three bombs that planted by perpetrator has exploded and five malaysian were injured[4]. During a recent Malaysia Grand Election of 2013, a man has slightly injured after an explosion believed to be from fire crackers has been exploded near Barisan Nasional command centre at Taman Jawi, Penang $[5]$.

Explosives can exist in the form of solid, liquid or gases. It is either made of mixtures or pure compounds [6].
Pure explosive compounds can further be divided into organic and inorganic explosives. Furthermore, explosive can be classified as low explosive and high explosive based on their impact of bombardment. Home-made explosive device is usually made from low explosive since the materials are commonly used and easily obtained by the public. Examples of low explosives are black powder, smokeless powder and propellant.

Common materials for home-made explosive devices may also come from pyrotechnics that can easily be obtained from the night market. Pyrotechnics mixed explosives are often used in making home-made explosives. It emerges as a potential threat to public security as pyrotechnics such as fireworks can be easily purchased either legally or illegally. Explosive substances include any materials for making any explosive substance and any bomb, grenade, apparatus, machine, implement, or material used or intended to be used or adapted for causing or aiding in causing any explosion or with any explosive substance and any part of such bomb, grenade, apparatus, machine or implement.

Proper investigation and analysis must be carried out because from the evidence collected at crime scene, the 
researcher can determine the type of explosive after the sample has been analyzed and can be used as evidence in court to link the suspect with the crime [7-9]

\section{EXPERIMENTAL}

\subsection{Materials}

The ionic analytes used for identification of explosives in this study comprise of several anions (chlorate, chloride, chlorite, fluoride, nitrate, nitrite, perchlorate, phosphate, sulfate, and thiocyanate). Standard solution of inorganic anions $\left(\mathrm{F}^{-}, \mathrm{Cl}^{-}, \mathrm{NO}_{2}^{-}, \mathrm{ClO}_{3}^{-}, \mathrm{NO}_{3}^{-}\right.$, $\mathrm{SO}_{4}{ }^{2-}, \mathrm{PO}_{4}{ }^{3-}$,) were prepared from $1000 \mathrm{mg} / \mathrm{L}$ stock solution respectively from Merck (Germany). Anion standards $\left(\mathrm{SCN}^{-}, \mathrm{ClO}_{4}^{-}\right)$were prepared from solid analytical grade potassium thiocyanate and potassium perchlorate from Merck (Germany).

\subsection{Instrumentation}

IC used in this study was a Metrohm Advanced IC system by Metrohm Ltd (Herisau, Switzerland). IC comprised of Methrohm 830 IC interface, 819 IC detector (conductivity detector), 820 column thermostat, 818 IC pump, separation column and guard column. For anionic separation, the column used was Metrosep A SUPP 5, 150 $\mathrm{x} 4.0 \mathrm{~mm}$ with $5 \mu \mathrm{m}$ particle size, and polyvinyl alcohol with quanternary ammonium groups as column packing material. For the eluent preparation of conventional IC separation, IC anion eluent consisting of $1.0 \mathrm{mmol} / \mathrm{L}$ of $\mathrm{NaHCO}_{3}$ and $3.2 \mathrm{mmol} / \mathrm{L} \mathrm{Na}_{2} \mathrm{CO}_{3}$ was prepared using 0.17 $\mathrm{g}$ of $\mathrm{Na}_{2} \mathrm{CO}_{3}$ and $0.04 \mathrm{~g}$ of $\mathrm{NaHCO}_{3}$ analytical grade (Merck, Germany) that was dissolved in a $500 \mathrm{~mL}$ of in a volumetric flask using DDW. Eluent was subjected to sonication for 15 minutes and filtered using a $0.45 \mu \mathrm{m}$ pore size, $47 \mathrm{~mm}$ diameter Whatman filter paper followed by degassing for 15 minutes. Flow rate of eluent was set at 0.7 $\mathrm{mL} / \mathrm{min}$. For supressor, $0.1 \mathrm{M}$ of sulfuric acid was prepared by dissolving $5.56 \mathrm{~mL}$ of sulfuric acid in $1 \mathrm{~L}$ volumetric flask of DDDW and mixed thoroughly. The solution was then filtered with $0.45 \mu \mathrm{m}$ nylon membrane filter.

\subsection{Sampling Exercise}

The sampling exercise was done in collaboration with Royal Malaysia Police from Forensic Laboratory in Cheras. The sampling was performed on 28th November 2012 at lapang sasar Pusat Latihan Polis Segamat, Johor which is located about $1 \mathrm{~km}$ from the main road. The weather was very sunny and not windy. Twelve plastic improvised explosives were made up from four different types of low-explosive pyrotechnic materials that can easily be obtained during festive celebration day in Malaysia. They were Mercun Ketupat, Happy Boom, Monster and Mercun Bola. $50 \mathrm{~g}$ of each explosive material was packed into PVC pipe container (Figure1).

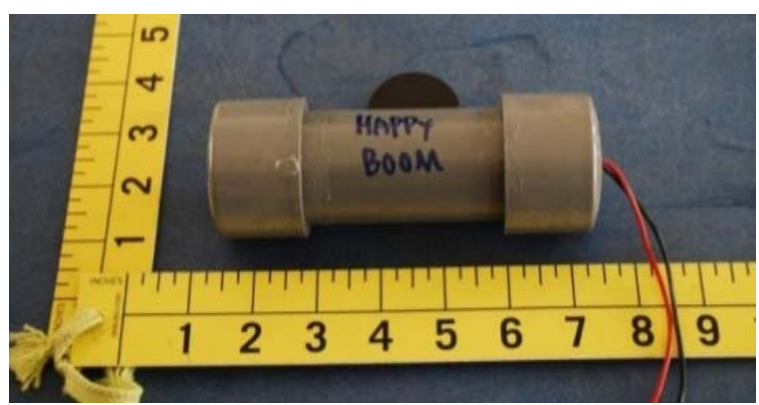

(a)

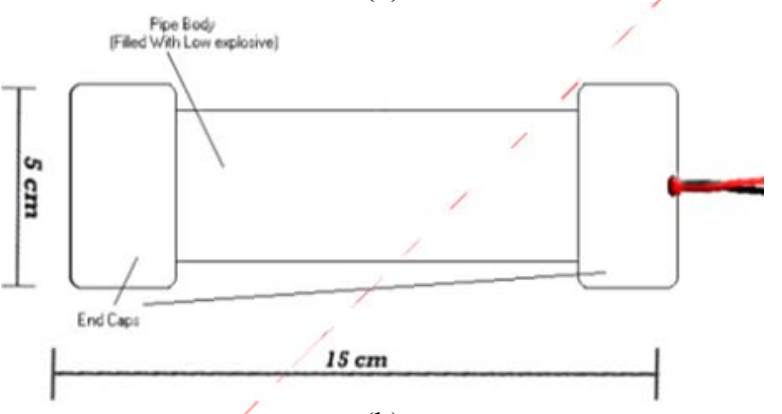

(b)

Fig. 1 (a) Photograph of home-made bomb and, (b) Dimensions of the PVC pipe used for the pipe bomb.

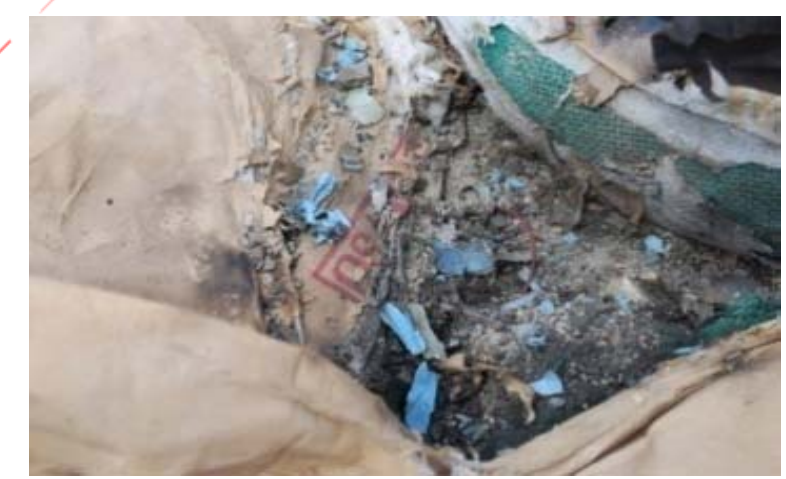

(a)

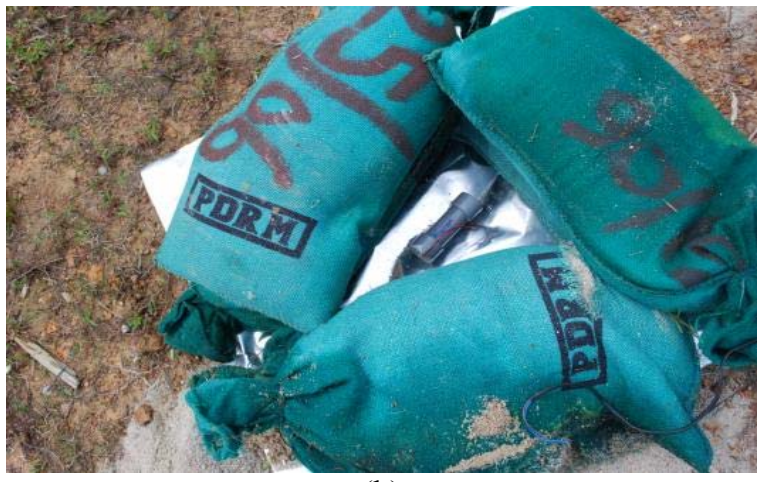

(b)

Fig. 2 (a) Arrangement of pipe bomb surrounded by sandbags before blast and, (b) Debris from seat of explosion ready to be collect. 
For every deflagration, seven sandbags and two sheets aluminium foil were needed. An aluminium foil was placed at the bottom and six sandbags were places in triangle multilevel layout before another aluminium sheet and sandbag was placed at the top (Figure 2). Four seats of explosion was set up according to four different types of PVC pipe bombs. Each of seat explosion was separated about 5 to $10 \mathrm{~m}$ apart in order to avoid cross contamination. A long cable was used in order to connect with the detonation wire of the explosive. For safety precautions, the seat of explosion was situated $70 \mathrm{~m}$ from the sheltered area and separated with small concrete wall (Figure 3). The explosive was fired off by using electrical discharge from a modified cell battery. From twelve bombs prepared only one of the bomb failed to be fired. All post-blast residues were collected in zip lock-plastic bag and placed in an ice cooled cooler box.

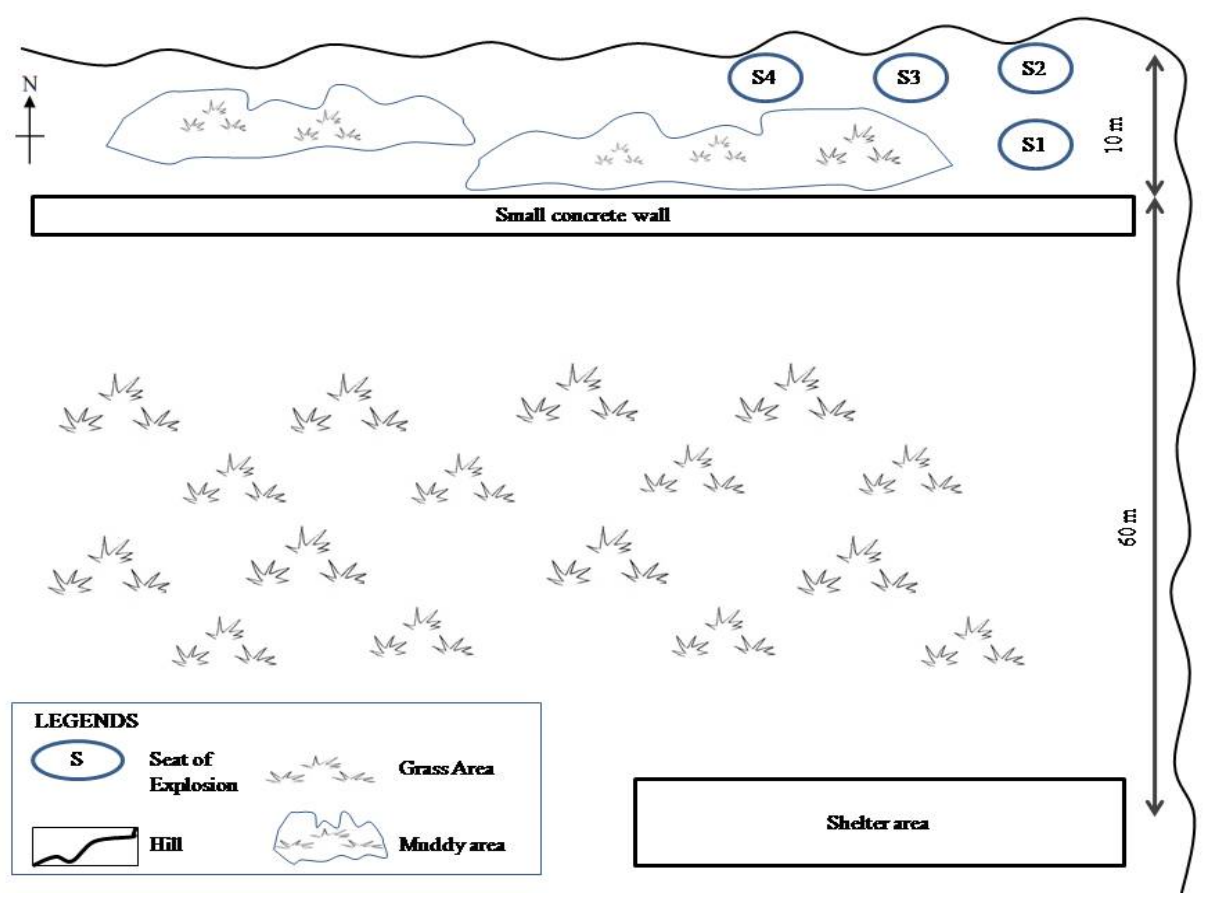

Fig. 3 Sketch of the Sampling Location

\subsection{Sampling procedure}

Pre-cleaning of cotton balls for swabbing process was initially carried out. The cotton balls were first cleaned by soaking in water for about two hours, followed by soaking in acetonitrile for another 2 hours. After the soaking process, the cotton balls were taken out and squeezed to remove excess solvent before left to dry at room temperature for 12 hours. Next, in the swabbing process of the post-blast residues, the cotton ball that being handled using forceps was moistened with $\sim 1 \mathrm{~mL}$ solvent (acetone) and immediately used to rub the surfaces of the pipe bomb fragments or any debris in order to collect the residue.

The swab was then placed inside a $50 \mathrm{~mL}$ plastic centrifuge tube containing $10 \mathrm{~mL}$ of acetonitrile. The cotton swab was then sonicated for 15 minutes and the extract filtered through a $0.45 \mu \mathrm{m}$ pore size syringe filter. The extract was transferred to a $10 \mathrm{~mL}$ vial, and subjected to dry under a gentle flow of nitrogen gas to near dryness. The extract was reconstituted using acetonitrile to bring the volume to $2 \mathrm{~mL}$. For IC analysis, $1 \mathrm{~mL}$ of extract was taken and further diluted to $10 \mathrm{~mL}$. The extract was then ready for chromatography analysis. A blank extraction was also prepared. The sample was labeled according to Table 1.

Table 1 Description of samples used in this study

\begin{tabular}{lll}
\hline \multicolumn{1}{c}{ Sample } & $\begin{array}{c}\text { Sample } \\
\text { Code }\end{array}$ & \multicolumn{1}{c}{ Description of Explosive Filler } \\
\hline Happy Boom & HB-PB & Granular form and grey in color \\
Monster & MS-PB & Irregular chip form and grey in color \\
Mercun Bola & MB-PB & Fine powder form and grey in color \\
Mercun Ketupat & MK-PB & Fine powder form and grey in color \\
\hline
\end{tabular}

\section{RESULTS \& DISCUSSION}

\subsection{Separation of standard anions}

For anionic analysis, Metrosep A Supp 5 was employed as the column. Using a mixture of $\mathrm{Na}_{2} \mathrm{CO}_{3}$ and $\mathrm{NaHCO}_{3}$ as the eluent at a flow rate of $0.7 \mathrm{~mL} / \mathrm{min}$, all the 
target anions were successfully separated within 50 minutes. Most anions were found to elute closely within 16 minutes except for thiocyanate that eluted around 35 minute and perchlorate at a much later retention time of around 45 minutes (Figure 4).

\subsection{Calibration, detection limits and repeatability}

Calibration graphs of anions were plotted using various concentration ofmixed standard solution from 1 $\mathrm{mg} / \mathrm{L}$ to $5 \mathrm{mg} / \mathrm{L}$ (Figure 5 ). Linear calibration graphs were obtained with good correlation coefficients (0.985-0.999). Detection limit in this study was comparable to previous work by Meng et al. who used ion chromatography as their instruments [10]. Limit of detection and correlation coefficient $\left(\mathrm{r}^{2}\right)$ of each analyte in this study were summarized in Table 2.

Reproducibility play important role in determining the accuracy and precision of data analysis including retention time and peak area under same condition. Relative standard deviation, RSD, was calculated to determine the precision of the method. In order to determine the reproducibility of the IC technique, $3 \mathrm{mg} / \mathrm{L}$ of standard anions was injected three times per day and also in three consecutive days. Perchlorate ion shows high, relative standard deviation because the stability was less compared to the other ions. Table 3 shows the reproducibility of retention time and peak area in IC separation.

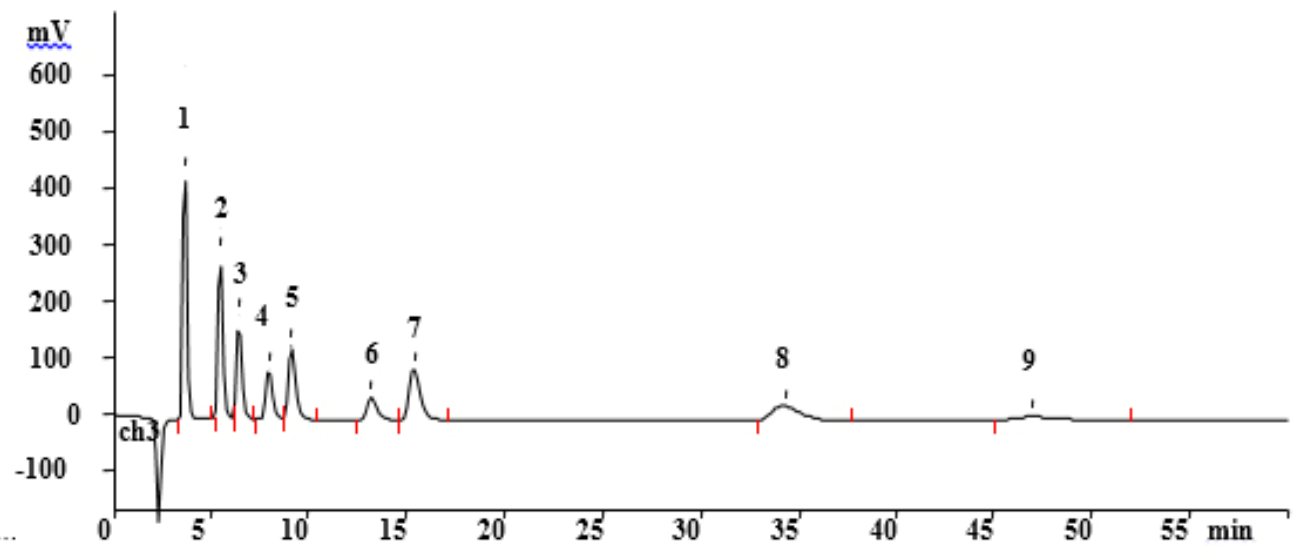

Fig. 4 IC chromatogram of $4 \mathrm{mg} / \mathrm{L}$ standard anions. IC conditions: Metrosep A SUPP 5 column ( 150 x $4.0 \mathrm{~mm}$ I.D. $)$ coated with polyvinyl alcohol with quaternary ammonium groups; $3.2 \mathrm{mM} \mathrm{Na} 2 \mathrm{CO}_{3}$ and $1.0 \mathrm{mM} \mathrm{NaHCO}$ eluent with flow rate of $0.7 \mathrm{~mL} / \mathrm{min}$; suppressed conductivity detection. Peak identities: (1) fluoride, (2) chloride, (3) nitrite, (4) chlorate, (5) nitrate, (6) phosphate, (7) sulphate, (8) thiocyanate and (9) perchlorate.

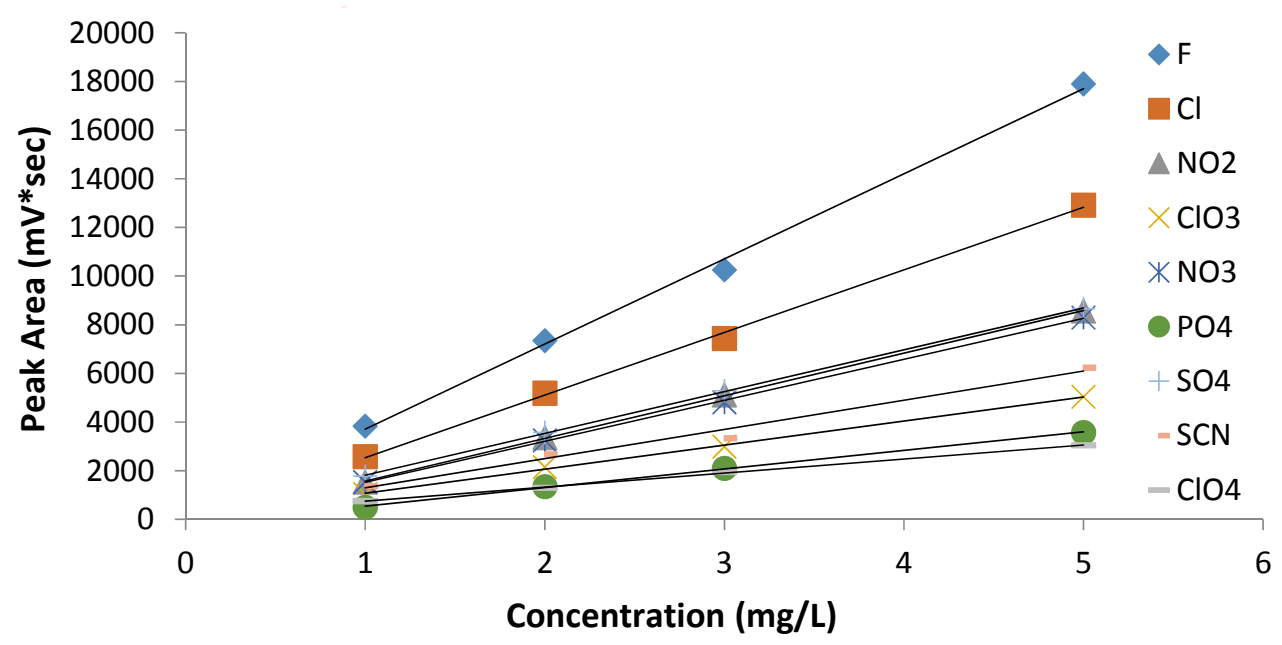

Fig. 5 Calibration graph of nine anions plotted using 1 to $5 \mathrm{mg} / \mathrm{L}$ concentration of standard solutions

Table 2: Detection limit data of each analyte and comparison LOD obtained with other study. 
M.A.M. Huri et al. / Malaysian Journal of Fundamental and Applied Sciences Vol.10, No.3 (2014) 144-149

\begin{tabular}{|c|c|c|c|c|}
\hline \multirow[t]{2}{*}{ Analytes } & \multicolumn{2}{|c|}{$\begin{array}{c}\text { Limit of Detection } \\
(\mathrm{ppm})\end{array}$} & \multirow[t]{2}{*}{ Equation } & \multirow[t]{2}{*}{$\begin{array}{c}\text { Correlation } \\
\text { coefficient }\left(\mathbf{r}^{2}\right)\end{array}$} \\
\hline & This study & *Meng et al. & & \\
\hline \multicolumn{5}{|l|}{ Anions } \\
\hline $\mathbf{F}^{-}$ & 0.35 & - & $y=3499 . x+208.3$ & 0.997 \\
\hline $\mathrm{Cl}^{-}$ & 0.28 & 0.12 & $y=2574 . x-46.44$ & 0.998 \\
\hline $\mathrm{NO}_{2}^{-}$ & 0.09 & 0.30 & $y=1753 . x-184.6$ & 0.999 \\
\hline $\mathrm{ClO}_{3}^{-}$ & 0.26 & 0.30 & $y=989.6 x+82.59$ & 0.998 \\
\hline $\mathrm{NO}_{3}{ }^{-}$ & 0.13 & 0.05 & $y=1684 . x-160.8$ & 0.999 \\
\hline $\mathrm{PO}_{4}{ }^{2-}$ & 0.22 & - & $y=763.5 x-221.1$ & 0.999 \\
\hline $\mathrm{SO}_{4}{ }^{2-}$ & 0.10 & 0.07 & $y=1717 x+101.1$ & 0.999 \\
\hline $\mathrm{SCN}^{-}$ & 0.84 & - & $y=1198 . x+103.3$ & 0.985 \\
\hline $\mathrm{ClO}^{-}$ & 0.22 & - & $y=576.9 x+169.8$ & 0.999 \\
\hline
\end{tabular}

Table 3 Relative standard deviation of retention time for each analyte within-day and day-to-day variation.

\begin{tabular}{ccccc}
\hline Analytes & \multicolumn{2}{c}{ Within-day RSD \% $(\mathbf{n}=\mathbf{3})$} & \multicolumn{2}{c}{ Day-to-day RSD \% (n=3) } \\
\cline { 2 - 4 } & Retention Time & Peak Area & Retention Time & Peak Area \\
\hline Anions & & & & 0.61 \\
$\mathbf{F}^{-}$ & 0.16 & 0.49 & 0.31 & 1.21 \\
$\mathbf{C l}^{-}$ & 0.38 & 8.17 & 0.38 & 2.23 \\
$\mathbf{N O}_{2}^{-}$ & 0.46 & 2.18 & 0.39 & 2.90 \\
$\mathbf{C l O}_{3}{ }^{-}$ & 0.62 & 0.46 & 0.50 & 1.54 \\
$\mathbf{N O}_{3}^{-}$ & 0.81 & 1.77 & 0.54 & 2.64 \\
$\mathbf{P O}_{4}{ }^{-}$ & 0.24 & 0.99 & 0.19 & 5.63 \\
$\mathbf{S O}_{4}{ }^{-2}$ & 0.07 & 1.55 & 0.78 & 5.91 \\
$\mathbf{S C N}^{-}$ & 1.84 & 2.34 & 0.92 & 9.38 \\
$\mathbf{C l O}^{-}$ & 3.13 & 16.82 & 0.97 & \\
\hline
\end{tabular}

\subsection{Peak ratio profile of pre-blast and post-blast analysis}

Chemical composition of each types of PVC pipe bomb sample is different from another. However most of the samples contains nitrate, sulphate, chlorate or perchlorate as their main oxidiers. Some critical changes can be observe between comparison of unexploded explosive and post-blast residues sample.

As shown in Table 4, anion and chlorate showed drastic reduction in post-blast samples $\mathrm{HB}$ and $\mathrm{PB}$. The changes in nitrate and sulfate suggested the presence of black powder in the sample. Black powder consists of potassium nitrate, sulfur and charcoal [11]. The oxidation of black powder will result in a decrease in nitrate and increase in sulfate (Equation 1).
$10 \mathrm{KNO}_{3}+3 \mathrm{~S}+8 \mathrm{C} \rightarrow 2 \mathrm{~K}_{2} \mathrm{CO}_{3}+3 \mathrm{~K}_{2} \mathrm{SO}_{4}+6 \mathrm{CO}_{2}+5 \mathrm{~N}_{2}$

In post-blast residues analysis, significant changes chloride ions were observed. Although the increase of ion may come from contamination of surrounding including soil and dust, according to McCord et al. [12], the increase of chloride is a result of chemical reduction of other oxidizers including $\mathrm{ClO}_{4}^{-}$and $\mathrm{ClO}_{3}{ }^{-}$(Equation 2).

$\mathrm{ClO}_{4}^{-} \rightarrow \mathrm{ClO}_{3}^{-} \rightarrow \mathrm{Cl}^{-}$

IC chromatogram of pre and post blast sample gave a unique 'chemical fingerprint' as shown in Figure 6 and Figure 7. These 'chemical fingerprint' can reveal the identity of the exact type of explosive in a sample.

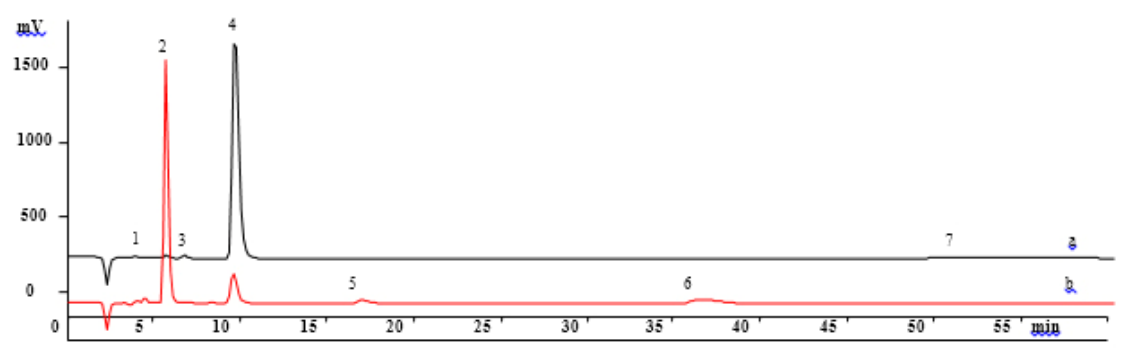

Fig. 6 IC chromatogram of target anions in unexploded explosive (a) and post-blast (b) residues of Sample HB-PB-1. IC conditions as in Figure 4. Peak identities: $1 . \mathrm{F}^{-}, 2 . \mathrm{Cl}^{-}, 3 . \mathrm{NO}_{2}^{-}, 4 . \mathrm{NO}_{3}{ }^{-}, 5 . \mathrm{SO}_{4}{ }^{2-}, 6 . \mathrm{SCN}^{-}, 7 . \mathrm{ClO}_{4}^{-}$. 


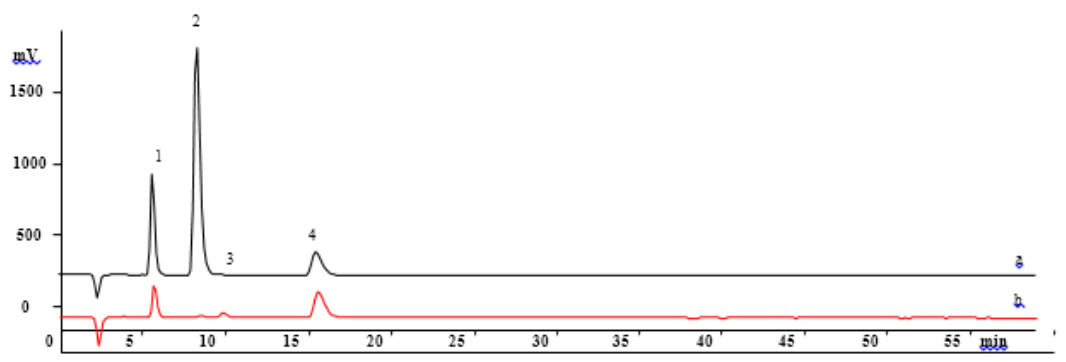

Fig. 7 IC chromatogram of target anions in unexploded explosive (a) and post-blast (b) residues of Sample MB-PB-1. IC conditions are same as in Figure 4. Peak identities: $1 . \mathrm{Cl}^{-}, 2 . \mathrm{ClO}_{3}^{-}, 3 . \mathrm{NO}_{3}^{-}, 4 . \mathrm{SO}_{4}^{2-}$

Table 4 Ratio of anions in unexploded explosive standard and post-blast PVC pipe bomb samples.

\begin{tabular}{|c|c|c|c|c|c|c|c|c|c|c|c|c|c|c|c|c|c|c|}
\hline \multirow{2}{*}{ Samples } & \multicolumn{9}{|c|}{ Unexploded Explosive Standard } & \multicolumn{9}{|c|}{ Post-blast samples } \\
\hline & $\mathbf{F}^{-}$ & $\mathrm{Cl}^{-}$ & $\mathrm{NO}_{2}{ }^{-}$ & $\mathrm{ClO}_{3}^{-}$ & $\mathrm{NO}_{3}^{-}$ & $\mathrm{PO}_{4}^{2-}$ & $\mathrm{SO}_{4}^{2-}$ & $\mathrm{SCN}^{-}$ & $\mathrm{ClO}_{4-}$ & $\mathbf{F}^{-}$ & $\mathrm{Cl}^{-}$ & $\mathrm{NO}_{2}^{-}$ & $\mathrm{ClO}_{3}^{-}$ & $\mathrm{NO}_{3}{ }^{-}$ & $\mathrm{PO}_{4}{ }^{2-}$ & $\mathrm{SO}_{4}^{2-}$ & $\mathrm{SCN}^{-}$ & $\mathrm{ClO}_{4-}$ \\
\hline HB & 1.32 & 1.75 & 2.23 & ND & 217.31 & ND & 1 & ND & 7.32 & 0.04 & 31.02 & 0.07 & ND & 6.17 & ND & 1 & 0.83 & 0.26 \\
\hline MS & 0.71 & 3.65 & ND & 1.27 & 234.64 & ND & 1 & ND & 0.90 & 0.46 & 35.78 & ND & 0.17 & 7.39 & ND & 1 & ND & ND \\
\hline MK & 0.56 & 0.85 & 0.09 & 0.20 & 0.26 & ND & 1 & ND & ND & 0.34 & 18.31 & 0.08 & ND & 0.95 & ND & 1 & ND & ND \\
\hline MB & ND & 1.88 & ND & 6.28 & ND & ND & 1 & ND & ND & ND & 0.55 & ND & 0.05 & 0.11 & ND & 1 & ND & ND \\
\hline
\end{tabular}

\section{CONCLUSIONS}

Composition profiles of low explosive compounds have been successfully determined by using ion chromatography. All target anions $\left(\mathrm{F}^{-}, \mathrm{Cl}^{-}, \mathrm{NO}_{2}^{-}, \mathrm{ClO}_{3}^{-}\right.$, $\left.\mathrm{SO}_{4}^{2-}, \mathrm{PO}_{4}^{3-}, \mathrm{ClO}_{4}^{-}\right)$were successfully separated within 60 minutes using Metrosep A Supp 5 column with of 1.0 $\mathrm{mmol} / \mathrm{L}$ of $\mathrm{NaHCO}_{3}$ and $3.2 \mathrm{mmol} / \mathrm{L}$ of $\mathrm{Na}_{2} \mathrm{CO}_{3}$ as the eluent. Linear calibration graphs were obtained with good correlation coefficients (0.985-0.999) and low limit of detection (0.1-0.9 $\mathrm{mg} / \mathrm{L})$. For the anion reproducibility, RSD of retention time were $0.16-2.21 \%$ (within day) and $0.19-1.09 \%$ (day to day). Meanwhile for RSD for peak area of anion were $0.46-16.82 \%$ (within day) and 0.61 $9.38 \%$ (day to day) respectively. Compared to another anions, perchlorate ion showed less reproducibility. RSD of retention time were $0.01-0.15 \%$ (within day) and 0.45 $0.68 \%$ (day to day). Each of the sample types bomb contained different composition profile of analytes presents.

\section{ACKNOWLEDGEMENT}

Thanks are due to the Department of Chemistry, Faculty of Science, Universiti Teknologi Malaysia, Johor for research facilities as well as to Malaysian Ministry of Higher Education for financial assistance through FRGS grant no R.J130000.7826.4F200. Collaboration assistance from Royal Malaysia Police is also greatly acknowledge.

\section{REFERENCES}

[1] U.K. Ahmad, O.S. Tze, M.F. Ghazali, Y.C. Hooi, and M.K. Abdullah, Malays. J. Anal. Sci. (2011). 213.

[2] Atlantuya Murder: It's Death for Azilah and Sirul (2009 April 9). The Star Online. Retrieved from http://hestar.com.my/news/story.asp?file/2009/4/9/nation/200904 $09093431 \&$ sec $=$ nation.

[3] D. Royds, S.W. Lewis, and A.M. Talanta, 67(2) (2005) 262.

[4] Five injured in two of three explosions outside KL Court (2012 January 9). The Sundaily Online. Retrieved from http://www.thesundaily.my/news/261108.

[5] GE13: Man slightly injured in rubbish dump explosion near BN ceramah (2012 April 24). The Star Online. Retrieved from http://thestar.com.my/news/story.asp?file=/2013/4/24/nation/1301 $7441 \&$ sec $=$ nation

[6] Akhavan, J. The Chemistry of Explosives. 2nd ed. U.K: The Royal Society of Chemistry, (2004) 18.

[7] U.K. Ahmad, and K.K. Heng, J. Teknologi C. 46 (c). (2007) 59

[8] S. Ladham, A.S. Koehler, P. Woods, R. Huston, J. Dominick, W.F. Fotchman, and H.C. Wecht, J Clin Forensic Med, 12(2): (2005) 82.

[9] R. Varga, P. Ulbrich, AARMS vol. 3, No. 4, (2004) 633.

[10] HB. Meng, TR. Wang, BY. Guo, Y. Hashi, CX. Guo, JM. Lin, Talanta. 76(2) (2008) 241.

[11] R. Saferstein, Criminalistics: An Introduction to Forensic Science. $\left(9^{\text {th }}\right.$ Ed). New Jersey: Person Prentice Hall. 2007.

[12] B.R. McCord, K.A. Hargadon, K.E. Hall, and S.G. Burmeister, Anal. Chim. Acta. 288 (1994) 43. 